\title{
STRUKTUR DAN ESTETIKA ANGGUK PUTRI “SRI LESTARI" DI DUSUN PRIPIH KULON PROGO
}

\author{
Suryati \\ Dosen tetap Jurusan Musik, FSP ISI Yogyakarta. Email: atik.jurasik@yahoo.com.
}

\begin{abstract}
The angguk is one among many types of the selawatan genre, it is an Indonesian traditional Islamic liturgical music. While the selawatan is normally perfomed by a group of men, the angguk includes a group of female dancers as the accompaniment to the selawatan musicians. This additional accompaniment accommodates the transformation form, from music to perfoming art. This study focuses on the analysis of structure and aesthetics of the performance of the "Sri Lestari" female angguk group in the Pripih village, at Kulon Progo district. The art was performed by young female dancers who were dressed in colorful costumes to attract the attention of audience. This study concludes that the performing art has been influenced by other type of the selawatan elements, such as the dolalak, which originated from Purworejo, Central Java. The angguk music which is very simple and monotous as the result of subsequent repetition with only little variations, is the verse reading effect of the pantun, which is a typical of traditional letter's vocal arts. While the pantun characterizes general musical structure, the instrumentation, rhythmic, and the tempo of the music, gives the essence of aesthetic meaning toward the genre. The dance has been used to enhance the performing aesthetics to invite the attention of the audience.
\end{abstract}

Keywords: Angguk, selawatan, aesthetics.

\begin{abstract}
Abstrak
Angguk adalah musik liturgis Islamis di Indonesia yang merupakan salah satu dari berbagai jenis selawatan. Sementara umumnya selawatan ditampilkan oleh kelompok pria, Angguk melibatkan kelompok tari wanita sebagai pengiring musisi-musisi selawatan. Penambahan iringan ini mengakomodasi bentuk transformasi, dari musik ke seni pertunjukan. Studi ini terfokus pada analisis struktur dan estetik penyajian kelompok Angguk putri "Sri Lestari" di desa Pripih, Kulon Progo. Seni tersebut ditampilkan oleh penari muda putri dengan pakaian yang berwarna-warni untuk menarik perhatian adiens. Studi ini menyimpulkan bahwa seni pertunjukan ini telah dipengaruhi oleh elemen-elemen selawatan, khususnya $n$ Dolalak, yang berasal dari Purworejo, Jawa Tengah. Musik Angguk yang sederhana dan monoton sebagai hasil pengulangan terus menerus dengan sedikit variasi adalah efek dari pembacaan pantun, yang merupakan seni vokal sastra. Sementara pantun mencirikan struktur musikal secara umum, instrumentasi, ritmis dan tempo musik tersebut memberikan esensi pengertian estetik terhadap jenis seni ini. Tarian telah digunakan untuk meningkatkan estetika penyajian untuk mengundang perhatian para audiens.
\end{abstract}

Kata Kunci: Angguk, selawatan, estetika 


\section{Pengantar}

\section{Latar belakang}

Kesenian adalah salah satu unsur kebudayaan yang merupakan hasil karya cipta manusia yang diwujudkan melalui ekspresi penghayatan estetis dengan latar belakang kehidupan dan kebudayaan atas sesuatu yang merangsang daya ciptanya, untuk memuaskan kebutuhan nalurinya akan keindahan (Malinowski, 1987:171). Kesenian memiliki peranan penting dalam kehidupan manusia, karena dengan senilah manusia dapat mencapai kehidupan spiritual yang penuh kedamaian dan kesejahteraan sebagai tujuan hidup. Hal ini ditegaskan oleh S. Budhisantoso bahwa kesenian sebagai ungkapan keindahan yang merupakan salah satu kebutuhan manusia yang universal. Kesenian bukanlah milk orang kaya atau orang yang serba berkecukupan, melainkan juga menjadi kebutuhan orang miskin atau yang hidup serba kesulitan (S. Budhisantoso, 1980:23).

Suatu kebudayaan yang menonjol adalah kesenian rakyat tradisional yang hidup dan berkembang ditengah-tengah masyarakat pedesaan. Kesenian tradisional pada umumnya diterima sebagai tradisi pewarisan yang dilimpahkan dari generasi tua kepada generasi muda (Jennifer Lindsay, 1991:40).

Setiap daerah pasti memililik kesenian rakyat yang oleh masyarakatnya selalu dibanggakan untuk menunjukan ciri khas dari daerahnya masing-masing. Kesenian rakyat ini bentuknya bermacammacam ada yang berbentuk musik, tari, ataupun drama. Hal ini sesuai yang diungkapkan oleh R.M. Soedarsono bahwa di Daerah Istimewa Yogyakarta terdapat beberapa kesenian rakyat antara lain: jathilan, reog, incling, badui, kuntulan, angguk, dan ada juga yang berbentuk dramatari (R.M. Soedarsono, 1976:1).

Adanya berbagai macam seni tradisional dalam kesenian tersebut, salah satu diantaranya mempunyai daya tarik tersendiri untuk dipaparkan dalam penulisan ini. Adapun kesenian yang dimaksud adalah kesenian angguk putri "Sri Lestari", sebagai kesenian tradisional yang tumbuh dan berkembang di Daerah Istimewa Yogyakarta khususnya di Dusun Pripih, Desa Hargomulyo, Kecamatan Kokap, Kabupaten Kulon Progo, yang hingga sekarang bagi masyarakatnya masih dilestarikan dan dipertunjukan pada peristiwa-peristiwa tertentu, misalnya untuk keperluan hajatan, nadhar, memperingati hari-hari besar, dan sebagainya.

Menurut W.J.S. Poerwadarminta istilah angguk berarti gerak menundukan kepala dengan pengertian tanda setuju (W.J.S. Poerwadarminta, 1976: 43). Jadi anggukan kepala dalam pengertian di atas merupakan gerak tubuh tertentu sebagai ungkapan perasaan manusia. Dalam seni tari hal ini terlihat jelas bahwa berbagai gerakan senuanya mengandung arti, gerak itu sendiri dibedakan atas isyarat dan sikap (Suwondo, 1977:254) 
Kesenian Angguk termasuk kesenian rakyat jenis selawatan yang bernafaskan Islam. Pada umumnya kesenian ini dipergunakan bagi masyarakat yang beragama Islam. Adapun kesenian yang bernafaskan Islam ada bermacam-macam, hal ini dapat dilihat dari syair lagunya yang bertemakan Islam, atau instrumennya yang biasanya menggunakan jedhor dan rebana. Salah satu ciri khas dan bentuk selawatan biasanya latar belakangnya selalu mengisahkan riwayat Nabi Muhammad S.A.W.

Berkaitan dengan hal tersebut di atas, maka masyarakat Pripih mengartikan gerak angguk yang dilakukan dalam tariannya sebagai ungkapan kegembiraan. Dalam hal ini diambil cerita perang Badar yakni peperangan antara kaum Muslimin dengan kaum Quraisy. Dalam peperangan tersebut Nabi Muhammad S.A.W. mendapat kemenangan, sehingga untuk merayakan kemenangan itu kaum Muslimin menyambut dengan beraneka cara antara lain; menabuh kendang, rebana, kecer, jedhor, dan nyanyian sambil menarinari dengan mengangguk-anggukan kepala. Maka dari itu kesenian tersebut disebut angguk.

Kesenian angguk ini pada mulanya digunakan sebagai dakwah Islam untuk syiar agama, karena syair-syair lagunya diambil dari kitab suci Al-Quran dan kitab Al-Barzanji yang dilagukan dengan diiringi instrumen yang terdiri dari jedhor, kendang dan gejreng (Kuntowijoyo, ed., 1986-1987:12). Selanjutnya group angguk putri "Sri Lestari" ini merupakan perkembangan dari group angguk putra Al-Mukmin. Awal dari terbentuknya group angguk putri "Sri Lestari" ini ditandai sejak perkawinan Surajiyo dengan Sri Wuryanti pada tahun $\quad 1986 . \quad$ Masing-masing mempunyai latar belakang dari seni, karena mereka lulusan dari SMKI Yogyakarta. Berdirinya group angguk putri "Sri Lestari" ini bertepatan dengan Hari Ulang tahun Kemerdekaan Republik Indonesia yang ke-46 yaitu pada hari Sabtu tanggal 17 Agustus 1991, karena group tersebut sebagai salah satu pengisi acara pementasan yang diadakan di Kecamatan Kokap.

Bentuk komposisi kesenian angguk merupakan gabungan dari instrumen, vokal dan tari. Adapun jumlah pemainnya terdiri dari 12 orang pemain musik dan vokal (sari suara) campuran putra putri, serta 12 sampai 18 orang penari yang semuanya wanita-wanita muda. Mereka menari dalam posisi berjajar dan berpasangan, kostum yang digunakan menggambarkan kebesaran panglima perang, yakni celana, baju dengan atribut kemiliteran, pet, slempang, kaos kaki dan biasanya dilengkapi dengan kaca mata hitam bagi yang trance.

Tata cara pertunjukannya lazimnya dibuka dengan tabuhan pambuko (pembukaan) dengan lagu Sugeng Rawuh (Selamat datang) untuk menandakan bahwa pertunjukan akan dimulai. Kemudian dilanjutkan dengan lagu-lagu lain bersama pena- 
rinya kurang lebih selama satu jam. Ditengah-tengah pertunjukan itu sesuai dengan tempo musik yang dimainkan bisa membuat seorang penari lupa diri (trance $=$ ndadi) . Diakhir pertunjukan penari yang trance tersebut dapat sadar seperti sedia kala setelah diberi mantra oleh pawangnya.

Dengan adanya perkembangan zaman dan didukung dengan adanya listrik masuk desa, peralatan elektronik maka angguk putri "Sri Lestari" ini mengalami perkembangan dan perubahan dengan tuntutan zaman. Perkembangan suatu kebudayaan sesuai dengan tuntutan zaman, merupakan produksi perubahan dari waktu ke waktu yang dapat disebabkan dari berbagai hal. Salah satu sebabnya adalah perubahan lingkungan yang dapat menuntut perubahan kebu-dayaan yang bersifat adaptif (Willam A. Haviland, 1993: 246)

Perubahan dan perkembangan yang terjadi pada angguk putri "Sri Lestari" terlihat pada instrumen musik, karena disini terdapat penambahan alat musik diantarnya: keyboard, gitar, bass, dan drum. Penambahan alat musik tersebut berawal dari adanya group-group campursari yang sudah merambah ke Dusun Pripih sekitar tahun 1994. Dengan adanya penambahan alat musik tersebut jelas mempengaruhi hasil musikalitas, penampilan serta penjiwaan yang estetis pada penyajiannya.
Berdasar uraian di atas, ternyata banyak masalah dan hal yang menarik untuk diungkapkan melalui penelitian ini, namun pada kesempatan ini akan dibatasi subjek penelitian dengan mencoba mencari jawaban antara lain: Keberadaan angguk putri "Sri Lestari", komposisi musik angguk "Sri Lestari" dalam bentuk penyajian, dan bagaimana estetika musik angguk putri "Sri Lestari" dalam bentuk penyajian dan pertunjukannya.

\section{Kerangka Teori}

Berdasarkan metodologi yang diterapkan di dalam melakukan proses penelitian, baik melalui kerja lapangan maupun laboratorium, maka diperlukan suatu landasan teori sebagai dasar dan pedoman dalam penyusunan karya ini.Untuk mengetahui keberadaan dan perkembangan musik tari angguk putri "Sri Lestari" di dusun Pripih Hargomulyo Kokap Kulon Progo Yogyakarta, akan dipakai suatu teori sejarah dalam melacak asal-usul musik tersebut dan perubahan yang terjadi menurut perkembangan zaman. Menurut Sartono Kartodirdjo “...esensi dari perspektif historis yaitu pandangan membujur mengikuti garis perkembangan sepanjang waktu tertentu. Dengan demikian akan tampak jelas bahwa situasi sekarang adalah hasil produk dari pertumbuhan atau perkembangan sejarah" (Sartono Kartodirdjo, 1993:57)

Secara teoritis genre musik ini dapat dikatakan sebagai sebuah 
bentuk musik yang mengalami perubahan dari bentuk aslinya. Salah satunya disebabkan adanya instrumen musik modern yang masuk ke Indonesia. Pada awalnya pertunjukan genre musik ini secara murni digunakan untuk syiar agama kemudian berubah menjadi kebutuhan masyarakat yang bersifat hiburan dan komersial. Dengan demikian perubahan yang terjadi pada genre musik tersebut perlu dilandasi dengan konsep perubahan kebudayaan seperti, akulturasi dan inovasi.

Khusus mengenai perubahan yang terjadi di dalam musik Kaemmer mengatakan:

Changes occur both in the sounds of music and in its meanings, uses, and function. Changes in the sound are essentially changes in style, a rather broad term that consists of several features. The most widely recognized area of the style change is modification in the structures of music performed in a given society. This type of change includes such things as the use of chordal techniques, modifications in the standard scale tones, or changes in rhythmic patterns (John Kaemmer, 1993:174)

Untuk mengkaji pembahasan tersebut dipakai sebuah teori musikologi dengan memakai buku-buku yang berkaitan tentang hal tersebut yaitu: analisis komposisi musik dan estetika musik.

\section{Metode Penelitian}

Penelitian ini menggunakan metode deskriptif analisis dan inter- pretatif dengan memanfaatkan data kualitatif. Dalam penelitian kualitatif seorang peneliti dituntut harus mampu mengeksplanasikan semua bagian yang bisa dipercaya dari sumber informasi yang diketahuinya serta tidak menimbulkan kontradiksi dengan interpretasi yang disajikan (R.M. Soedarsono, 1999:27). Adapun pendekatan yang digunakan adalah pendekatan multidisipliner dengan metode utama musikologi yang ditunjang dengan konsep-konsep antropologi sosiologi, dan historis.

Pendekatan musikologis yang dimaksud dapat digunakan untuk mengkaji struktur musikal secara analisis struktural dari musik tari angguk, sedangkan pendekatan sosiologi dan antropologi dapat digunakan untuk mengungkapkan perilaku pemain musiknya di tengah-tengah masyarakat pendukungnya. Tak kalah pentingnya juga melalui pendekatan historis untuk mendapatkan keterangan secara jelas tentang latar belakang dari beberapa aspek yang berkaitan dengan proses pembentukan dan perkembangan musik tari angguk putri "Sri Lestari" di Dusun Pripih Kulon Progo.

Untuk menghimpun data-data tersebut maka diperlukan wawancara baik secara formal maupun non formal dengan cara merekam dan mengambil dokumentasi, dalam pengolahan data tersebut dibantu dengan sumber kepustakaan yang terpilih. 


\section{Pembahasan}

\section{Keberadaan Angguk Putri "Sri Lestari"}

Pada umumnya masyarakat Daerah Istimewa Yogyakarta, khususnya orang-orang yang mengenal ciri khas angguk putri dari Kulon Progo, tidak dapat melepaskan nama Pripih yaitu dusun asalnya dan "Sri Lestari" nama kelompok angguk tersebut. Penelitian ini sengaja mengambil contoh kelompok "Sri Lestari" karena kelompok tersebut merupakan salah satu dari kelompok angguk putri yang ada di Desa Hargomulyo yang paling eksis di mata masyarakat.

Awal mula terbentuknya kesenian angguk di dusun Pripih sekitar tahun 1950-an, baik penari maupun pemain musiknya dilakukan oleh kaum laki-laki dengan sebutan angguk Al-Mukmin. Kelompok kesenian tersebut beranggotakan 16 orang baik pemain musik maupun penarinya dan hanya berjalan kurang lebih 15 tahun. Pada saat itu kesenian tersebut belum bisa terorganisasi dengan baik, hanya kesadaran masyarakatnya sendiri yang ingin melestarikan dan cinta dengan kesenian tradisionala.

Kemudian dengan adanya kesibukan-kesibukan lain dari masing-masing anggota, kurang lebih 8 tahun kelompok kesenian sempat vakum tidak aktif lagi dan sulit untuk berkumpul lagi walaupun akan ada pementasan.

Sekitar tahun 1980-an salah satu warga di Dusun Pripih mempunyai keperluan hajatan untuk merayakan pesta pernikahan dari pasangan Surajiyo dan Sri Wuryanti, mereka mengundang kelompok angguk putri dari daerah Purworejo yang oleh masyarakatnya dikenal dengan sebutan dolalak. Ternyata pertunjukan tersebut disambut baik dan meriah oleh masyarakat dusun Pripih maka dari itu dengan adanya pertunjukan kelompok angguk tersebut dapat menggugah semangat masyarakat Pripih untuk menghidupkan kembali angguk yang mereka miliki.

Kurang lebih 2 tahun setelah adanya pertunjukan kelompok angguk putri dari Purworejo, masyarakat Pripih kembali mengaktifkan kelompok angguk yang para anggotanya terdiri dari kaum laki-laki. Kelompok tersebut diketuai oleh bapak Muhdiono selaku orang yang dipercaya dan tokoh masyarakat yang menjabat sebagai kaum di dusun Pripih. Pada saat itu jumlah kelompok angguk tersebut kurang lebih 20 anggota baik pemain musik maupun penarinya. Alat musik yang mereka gunakan diantaranya: satu buah kendang, satu buah bedhug, satu buah kecer, dan tiga buah rebana (tiga warna laras) lagu-lagunya mengambil dari kitab $\mathrm{Al}$ Barzanji (berjanjen).

Dalam rangka memperingati Hari Ulang Tahun Kemerdekaan Republik Indonesia yang ke-46, tepatnya hari Sabtu tanggal 17 Agustus 1991, kelompok angguk AlMukmin yang ada di Dususn Pripih diminta untuk tampil dalam acara pentas seni yang diadakan di 
Pendopo Kecamatan Kokap. Namun pada kesempatan tersebut remajaremaja Dusun Pripih ingin menampilkan kesenian angguk AlMukmin dengan mengubah para penarinya diganti dengan para wanita-wanita muda, yang kebanyakan remaja-remaja putri usia antar 15 sampai 25 tahun, seperti halnya kesenian dolalak dari daerah Purworejo yang pernah pentas di Dusun Pripih.

Dalam mewujudkan suatu penampilan yang memuaskan dibutuhkan persiapan yang matang. Persiapan itu dipimpin oleh Surajiyo bersama istrinya Sri Wuryati, didasari atas kepercayaan dari dorongan masyarakat dan keinginan untuk menghidupkan kembali kesenian angguk yang ada di dusun Pripih. Penataan musiknya digarap oleh Surajiyo yang asli penduduk Pripih, sedangkan dalam penataan tarinya digarap oleh Sri Wuryani yang berasal dari desa Bayan Purworejo juga mantan penari dolalak.

Ternyata pementasan mereka disambut meriah dan dapat memukau para penonton baik dari masyarakat Pripih sendiri maupun dari masyarakat pendukung lainnya. Disamping itu juga para pejabat kecamatan serta para pamong desa juga menyambut dengan baik, bahkan mendukung keberadaan kelompok angguk dengan para penari putri. Pada saat itu pula tanggal 17 Agustus 1991 seusai pertunjukan diresmikannya kelompok angguk tersebut dengan sebutan angguk putri "Sri Lestari".
Pemberian nama "Sri Lestari" oleh R. Sastroharjono selaku Kepala Desa Hargomulyo dan diresmikan oleh Suharjono selaku Camat Kecamatan Kokap sekaligus dibentuk suatu organisasi. Kelompok angguk ini diketahui oleh R. Joko Mulyanto, seorang pamong desa dan tokoh masyarakat dusun Pripih.

Makna dari nama "Sri Lestari"
bagi masyarakat Pripih adalah
disamping penari-penarinya terdiri
dari wanita-wanita muda dalam
pengertian lain juga untuk
melestarikan kebudayaan tradisional
agar tetap lestari dan berkembang.

\section{Bentuk Penyajian Angguk Putri "Sri Lestari"}

Sistem pementasan yang dilakukan oleh kelompok angguk putri "Sri Lestari" ini menggunakan sistem paket yaitu dengan paket pendek dan paket panjang. Dalam paket pendek mereka melakukan pertunjukan diantara 30 menit hingga satu jam pada umumnya menyuguhkan dengan satu babak, sedangkan dalam paket panjang mereka melakukan pertunjukan semalam suntuk yang dimulai dari jam 21.00 sampai 03.00 dini hari, untuk paket panjang biasanya menyuguhkan di antara empat sampai lima babak. Adapun jenis pertunjukan yang sering dilakukan oleh kelompok angguk putri ini adalah dalam paket panjang.

Berkaitan dengan uraian diatas, maka susunan atau bentuk penyajian kelompok angguk putri "Sri Lestari" yang biasanya dipertunjukan diatas 
panggung terbuka, yaitu merupakan gabungan musik instrumen, vokal, dan tari. Ketiga unsur ini merupakan satu kesatuan bentuk kelompok angguk yang tidak dapat dipisahkan satu sama lainya.

Adapun jumlah pemainnya terdiri dari 15 orang sebagai pemain musik dan vokal yang masing-masing memainkan satu buah kendang, satu buah bedhug, satu buah keyboard, satu buah gitar, satu buah bass, satu set drum, satu buah kecer, dan tiga buah rebana dengan tiga titi laras, serta dengan lima orang sebagai penyanyi (vokal) lagu-lagu yang dibawakan menggunakan bahasa Indonesia dan bahasa Jawa, sedangkan jumlah penarinya selalu genap diantara 12 sampai 18 orang.

Dalam penyajian angguk tersebut irama musiknya dari awal hingga akhir pertunjukan selalu sma, hanya saja dapat perbedaan dalam lagu-lagunya yang biasanya disesuaikan dengan tariannya. Tarian yang selalu dimainkan pada setiap pertunjukan diantaranya tari jalanjalan, tari pagi-pagi, tari ambil kain, dan tari ikan cucut. Bentuk penyajiannya, pertunjukan ini diawali dengan musik yang membawakan lagu Selamat Datang atau Sugeng Rawuh, Kulon Progo Binangun, dan lagu-lagu lainnya kurang lebih tiga atau empat lagu dengan maksud untuk menandai bahwa pertunjukan akan dimulai.

Pagi, Ikan Cucut, Jalan Terus, dan Parikan-parikan saat ini komposisi penarinya berpasangan biasanya berjumlah 2 kemudian disusul yang lainnya sehingga menjadi 7 orang membentuk lingkaran satu orang penari berada di tengah. Setelah selesai pada komposisi tersebut dilanjutkan dalam komposisi jejeran lagi (berjajar) pada saat ini ditengah-tengah permainan dengan tempo yang semakin cepat dan dinamik yang keras yang dapat menyebabkan salah satu penarinya lupa diri dengan kata lain ndadi (trance). Hal ini ditegaskan juga oleh Gilbert Rauget bahwa percepatan tempo dan dinamik keras digunakan secara universal sabagai sarana untuk memicu trance, karena irama yang lebih cepat dan nada yang mendayudayu dapan membuka otot-otot, organ dalam, kepala kesentuhan dewa (Gilbert Rauget, 1985: 81).

Untuk mengiringi penari yang akan kesurupan atau trance ini yang biasanya digunakan pada kelompok angguk putri yaitu: lagu Tresnowati, Kuning-kuning, Umarmoyo Wuyung, karena menurut kepercayaan kelompok angguk "Sri Lestari" lagu Umarmoyo ini untuk memanggil rohnya. Setelah seorang penari kesurupan biasanya meminta lagu-lagu yang berirama keras seperi lagu-lagu dangdut yaitu Kuda Lumping, Pri Idaman, serta lagu-lagu campursari seperti Hewes-Hewes, Parangtrirtis dan masih banyak lagi.

Pada saat seorang penari trance bisa bertahan menari sampai 10 lagu dengan gerak-gerak tari secara spontan dan bebas sesuai irama musiknya dan terdapat gerak 
maknawi sebagai gerak spontan, seperti halnya penari solo. Di dalam pementasan angguk ini biasanya disediakan sesaji (sajen Jawa), yang tujuannya untuk meminta selamat kepada roh-roh (sing mbaukrekso) agar tidak menggangu selama diadakan pementasan angguk tersebut. Adapun macam-macam sesaji tersebut adalah sirih ayu, pisang raja, nasi tumpeng, kendhi klowohan, kembang telon, daun dadap, kemenyan, ayam panggang, telur ayam kampung, jajan pasar, air tape, benang lawe, wajib (berbentuk uang), tikar kecil, penguripan (ayam kecil hidup). Sesaji tersebut sebelum pementasan dimulai biasanya diserahkan kepada pawang kesenian angguk.

Penari yang ndadi (trance) biasanya meminta sesaji tersebut untuk dimakan, kemudian selalu mendekat pada instrumen kendang dan bedhug karena instrumen tersebut dianggap keramat. Hal ini diungkapkan pula oleh Kuntowijoyo bahwa instrumen kendang dan jedhor (bedhug) tidak saja instrumen biasa melainkan mempunyai kekeramatan sebagai tempat tinggal roh, di dalam adegan ndadi pada angguk penari tersebut kemasukan roh Umarmaya. Maka dari itu seorang yang sedang trance dapat sadar seperti semula setelah diberi lagu Umarmaya Wuyung dan diberi mantra oleh pawangnya. Pertunjukan angguk ini dapat dikatakan selesai dalam satu babak setelah seorang penari yang ndadi (trance) dapat sadar seperti semula, kurang lebih memekan waktu 60 menit (satu jam).

\section{Estetika Musik Angguk Putri "Sri Lestari"}

Berbicara estetika adalah berbicara hakikat keindahan sebuah karya seni, dalam hal ini seni musik. Estetika musik di sini dimaksudkan sebagai pengetahuan atau usaha penelaahan tentang hubungan antara cita rasa dengan kesadaran intelektual manusia dengan musik (Suka Hardjana, 1983:11).

Beberapa filsuf telah mengemukakan teori-teori tentang estetika dengan berbagai pendapat yang mereka kemukakan. Kita sebut saja tokoh-tokoh itu antara lain: Plato (427347 SM)., Aristoteles (384-322 SM)., Aristoxenus (350-300 SM). Beberapa tokoh tersebut merupakan filsuf-filsuf yang telah mengemukakan bahwa estetika adalah tidak dapat dilepaskan dari keindahan dan kebaikan (keluhuran budi), jika konteks karya seni tersebut kita cermati pada zaman dimana para ahli estetika itu hidup. Menurut Suka Hardjana, bahwa estetika sebagai filsafat keindahan tentulah akan lebih leluasa dalam membahas obyeknya. Penulis sependapat dengan apa yang dikemukakan oleh para ahli estetika tersebut, karena kaidah sebuah karya seni memang demikanlah adanya.

Mengutip seperti apa yang dikemukakan oleh ahli estetika lain yaitu seorang filsuf Jerman Baumgarten (1714-1762) yang hidup jauh sesudah masa filsuf-filsuf seperti 
yang disebutkan sebelumnya, membedakan adanya tiga kesempurnaan di dunia ini, antara lain: (1) Kebenaran ialah kesempurnaan yang bisa ditangkap dengan rasio, (2) Kebaikan ialah kesempurnaan yang kita tangkap dengan moral kita, (3) Keindahan ialah kesempurnaan yang kita tangkap dengan indera kita (Soedarso Sp, 1990:39)

Berpijak pada teori estetika Baumgarten inilah penulis akan mengkaji estetika musik angguk. Perubahan dan perkembangan yang terjadi pada musik angguk dapat dikaji dengan menggunakan teori yang telah disebutkan, atau dengan kata lain aspek-aspek perubahan dan perkembangan musik angguk terutama dalam estetikanya tercakup dalam teori Baumgarten baik secara langsung maupun tidak lang-sung.

Perjalanan panjang musik angguk dengan segala perubahannya merupakan sebuah upaya dari masyarakat pendukung musik ini guna mencapai tingkat estetika musik angguk yang sesuai dengan fungsinya. Pembahasan di atas seperti yang telah penulis paparkan sebelumnya tentang perkembangan musik angguk, sehingga terwujudlah musik angguk seperti sekarang ini. Hal tersebut ditegaskan juga oleh I Made Bandem yaitu sebagai berikut:

Pada kenyataannya, kemampuan untuk menciptakan adalah sifat khusus dari manusia. Desakan untuk membuat dan menikmati apa yang kita sebut seni telah menjadi sebuah kekuatan pendorong sepanjang sejarah hidup manusia. Seluruh masyarakat telah menghasilkan objek-objek dan upacara-upacara yang meneruskan hubungan dan memenuhi kebutuhan fisikal dan spiritual. Beberapa objek dari alat-alat sederhana sampai alat-alat sakral yang kompleks telah direncang untuk memenuhi kebutuhan fisikal dan spiritual secara simultan (I Made Bandem, 2001:4)

Apa yang dikemukakan oleh I Made Bandem, jika dikaitkan dengan perkembangan atau perubahan yang terjadi pada musik angguk terdapat relevansi diantara keduanya.

Perubahan-perubahan yang terjadi pada perkembangan musik angguk merupakan salah satu upaya pencarian formasi musikal, baik secara organologis dan juga struktur musik yang bergayut di dalamnya persoalan estetika. Organologi musik angguk dan struktur musik angguk adalah dua aspek yang merupakan landasan dasar dalam memaparkan estetika musik angguk putri "Sri Lestari".

\section{Tahapan Estetika}

Pemaparan tentang estetika musik angguk yang akan penulis kemukakan, pembahasannya akan penulis klasifikasikan ke dalam dua kategori pemaparan, antara lain: (1) Estetika musik angguk pada tahapan pertama; (2) Estetika musik angguk 
pada tahapan kedua (musik angguk yang dikenal sekarang ini)

Adapun pemaparannya sebagai berikut:

\section{a. Estetika Musik Angguk Tahapan Pertama}

Apabila kita mengamati organologi musik yang berkaitan dengan instru-mentasi (alat musik) yang digunakan oleh kelompok musik angguk pada tahapan pertama yaitu sekitar tahun 1950-an, maka dapat dikatakan bahwa alat musik yang digunakan pada waktu itu lebih didominasi warna suara alat musik perkusi. Adapun alat musik perkusi yang dimaksudkan diantaranya: bedug, kendang, rebana dan kecer atau kecrek. Gambaran estetika musik ditinjau dari fungsi masing-masing alat musik tersebut adalah sebagai berikut:

- Bedug merupakan alat musik perkusi yang memiliki register suara bawah (bas), dengan demikian secara estetika musiknya, kesan yang hadir pada alat musik ini adalah sebagai aksentuasi (penguat) ritmik, atau dalam kata lain sebagai pembawa tempo.

- Kendang merupakan alat musik perkusi yang memiliki register suara medium, dengan demikian secara estetika musiknya kesan yang hadir pada alat musik ini adalah sebagai pembawa variasi pola ritmik tertentu sesuai dengan irama musik yang dimainkan.

- Rebana merupakan alat musik perkusi yang memiliki register suara yang terdiri dari beberapa pitch (biasanya terdiri dari berbagai ukuran), tergantung penggunanya. Alat musik ini merupakan kontra ritmik dan sekaligus variasi dari pola ritmik kendang.

- Kecrek merupakan alat musik perkusi yang memiliki register suara atas, merupakan alat musik yang digunakan sebagai kontra filler dari alat musik bedug.

Selain pemaparan estetika musik angguk dari sisi instrumenttasinya, penulis akan memaparkan juga estetika musik angguk yang berkaitan dengan teks serta konteksnya. Teks dalam hal ini berkaitan dengan melodi dan syair.

Melodi pada musik angguk menggunakan sistem tangga nada pentatonik, dalam hal ini Jawa. Melodi yang penulis maksudkan adalah merupakan melodi lagu-lagu yang sudah popular di kalangan masyarakat pendukung musik angguk, hanya saja syairnya menggunakan syair-syair yang berasal dari kitab AlBarzanji. Sesuai dengan fungsi musik ini pada mulanya, maka konteks yang penulis pahami adalah mengarah kepada religiusitas atau dalam kata lain, musik ini merupakan tuntunan dan syair agama Islam. Dalam kaitanya dengan estetika musik, sebagai musik religius tentu saja keindahan musik angguk mengekspresikan keagungan dan kebesaran Tuhan, yang pada akhirnya mengarah ke persoalan baik dan buruk di dalam diri manusia. 
Estetika musik angguk seperti yang telah penulis paparkan sebelumnya adalah estetika yang dikaji berdasarkan melodi dan syairnya. Pembahasan elemen musik lainnya yaitu ritme. Dalam analisis yang telah penulis lakukan, pada kenyataanya secara esensial bahwa ritme pada musik angguk bersifat monoton dalam artian ritme yang sama diulang-ulang. Pengulangan ritme secara terus menerus dan tempo semakin cepat berpengaruh bagi pendengarnya, pengaruh tersebut dapat dilihat dari gejala para pemain dan bahkan penontonnya konon kadang-kadang mengalami trance.

Pengulangan ritme dan perubahan tempo musik yang semakin cepat adalah merupakan ciri utama musik angguk. Jika dikaitkan dengan estetika musik angguk, penggunaan secara dominan alat musik perkusi, maka dapatlah dikatakan bahwa estetika musik angguk terletak pada ritmik dan temponya.

Perubahan organologis dalam hal alat musik yang digunakan serta perubahan personil pendukung musik angguk, secara langsung berpengaruh terhadap estetika musik angguk, dan perubahan estetika musik angguk itu akan penulis kaji pada bahasan tahap kedua.

\section{b. Estetika Musik Angguk Tahapan Kedua}

Sebagaimana yang telah penulis paparkan sebelumnya, bahwa personil pendukung musik angguk pada tahap ini terjadi pergantian, tidak lagi hanya beranggotakan jenis kelamin laki-laki tetapi perempuan juga. Selain itu, terjadi penambahan alat musik seperti gitar bas, dan keyboard atau dengan kata lain imbas modernisasi seperti alat musik elektrik turut mewarnai perkembangan musik angguk. Penyebab semua ini karena pengaruh yang diakibatkan munculnya musik campur sari.

Jika dikaji perkembangan dan perubahan besar pada musik angguk menjadikan musik angguk secara estetika mengalami pergeseran fungsi, dari musik religius menjadi musik hiburan atau dengan kata lain "form follows function". Secara langsung struktural musik, terutama dalam hal syairnya tidak berlandaskan pada kitab Al-Barzanji lagi, melainkan syair lagu musik-musik hiburan.

Dari uraian di atas, maka dipandang dari sudut estetika musik umumnya dan musik angguk khususnya, mengalami pergeseran fungsi musik angguk yang semula berfungsi sabagai sarana syiar agama atau bersifat religius, berkembang menjadi angguk seperti sekarang ini adalah akibat dari pengaruh estetika musik itu sendiri. Dengan kata lain, dengan penambahan alat musik gitar bas dan keyboard serta peran penari wanita dalam musik ini, mengubah estetika musik ini menjadi musik hiburan.

\section{Penutup}

Berdasarkan pembahasan struktur dan estetika musik angguk "Sri Lestari" di atas dapat disim- 
pulkan bahwa pertunjukan angguk yang hidup dan berkembang di masyarakat Pripih dapat dikatakan sebagai transformasi dari pertunjukan dolalak. Perubahan musik menjadi bentuk baru ini melalui proses yang bergulir mengikuti perkembangan zaman. Faktor yang melandasi perubahan tersebut dikarenakan adanya kemajuan manusia di berbagai bidang, terutama kemajuan pendidikan, teknologi, dan ekonomi yang berkaitan dengan kemajuan ilmu pengetahuan. Kelangsungan hidup angguk sejak munculnya hingga sekarang dapat mampu bertahan karena dibutuhkan oleh masyarakat pendukungnya. Sementara perubahan yang terjadi dalam bentuk musiknya merupakan sebuah tatanan baru dalam kehidupan kesenian rakyat yang dilandasi oleh kemajuan zaman. Kesederhanaan dalam bentuk lagu angguk, jika ditinjau dari segi estetika musiknya akan terlihat pada kecepatan temponya untuk memicu trance penarinya. Hadirnya alat musik baru dan pergantian para penarinya menyebabkan pergeseran fungsi pertunjukan angguk, yang semula sebagai syiar agama berkembang menjadi hiburan atau komersial.

\section{Referensi}

Bandem, I Made. Metodologi Penciptaan Seni. Yogyakarta: Program Pasca Sarjana ISI, 2000.

Budhisantoso, S. "Kesenian Dan NilaiNilai Budaya" dalam Analisis Kebudayaan. Jakarta:

Departemen Dan
Kebudayaan, Tahun I nomor 2, 1980.

Hardjana, Suka. Estetika Musik. Jakarta: Departemen Pendidikan dan Kebudayaan Direktorat Jendral Pendidikan Dasar dan Menengah, 1983.

Haviland, William A. Antropologi Jilid 2. Jakarta: Erlangga, 1993. Terjemahan R.G. Soekatijo.

Kaemmer, John. Music In Human Life: Anthropology Perspective on Music. Austin: University Of Texas Press, 1993.

Kartodirdjo, Sartono. Pendekatan Ilmu Sosial Dalam Metodologi Sejarah. Jakarta: PT. Gramedia Pustaka Utama,1993.

Kuntowijoyo,ed. Tema Islam Dalam Pertunjukan Rakyat Jawa: Kajian Aspek Sosial, Keagamaan, Dan Kesenian. Yogyakarta: Javanologi, 1986-1987.

Lindsay, Jennifer. Klasik Kitsch

Kontemporer Sebuah Studi

Tentang Seni Pertunjukan Jawa.

Yogyakarta: Gadja Mada University Press, 1991. Diterjemahkan oleh Nin Bakdi Sumanto.

Malinowski. "Teori Fungsional dan

Struktural" dalam

Koentjaraningrat Teori

Antropologi. Jakarta:

Universitas Indonesia Press, 1987.

Poerwadarminta, W.J.S. Kamus Umum Bahasa Indonesia. Jakarta: PN Balai Pustaka, 1976.

Rouget, Gilbert. Music And Trance A theory of the Relations Between 
74 | Promusika, Vol. 1, No. 1, April 2013

Music and possession. Chicago and London: The University of Chicago Press, 1985.

Soedarsono, R.M. Tari-tarian Rakyat di Daerah Istimewa Yogyakarta. Yogyakarta: Akademi Seni Tari Indonesia, 1976. - Metodologi Penelitian Seni Pertunjukan dan Seni Rupa. Bandung: Masyarakat Seni Pertunjukan Indonesia, 1999.

Soedarso Sp., Sebuah Pengantar Untuk Apresiasi Seni. Yogyakarta: Suku Dayar Sana, 1990. 